\title{
Cultural aspects of ants, bees and wasps, and their products in sub-Saharan Africa
}

\author{
Arnold van Huis ${ }^{1}$
}

Received: 11 October 2020 / Accepted: 18 December 2020 / Published online: 4 March 2021

(C) The Author(s) 2021

\begin{abstract}
This study's purpose was to make an overview of how ants, bees, wasps, and their products, such as honey are utilized, perceived, and experienced in daily life across sub-Saharan Africa. Ethno-entomological information was collected by interviews with more than 300 people from 27 countries and by literature studies. Queens of the ant Carebara vidua are deliberately eaten and unintentionally bee larvae with honey and sugar ants with sugar. Honey, apart from food, is widely used to treat numerous medical problems and as a stimulant (for the memory) or as a cosmetic. In the Qur'an, the medical value of honey is recognized. Seed stores of ants may be harvested by humans. In Sudan, bee stings are used to cure arthritis as bee venom has bioactive properties. Wasp nests are used to cure inflammations such as mumps. Certain insect properties are used in conveying these treatments to persons it is employed to, such as wasps feed do make dogs vicious. Some stories seem to make no sense like the snake-trapping ants in Madagascar, but a scientific explanation is provided. Certain insects' looks may inspire people to construct stories or have proverbs such as the very narrow waist of wasps, suggesting sterility. Bee swarms and driver ants are feared all over and believed to be employed (by witchdoctors) to punish. Not all stories of events with bees or ants are similar across sub-Saharan Africa. Social insects are also used to stimulate cohesion between people.
\end{abstract}

Keywords Ant $\cdot$ Bees $\cdot$ Ethno-entomology $\cdot$ Traditional medicine $\cdot$ Honey $\cdot$ Wasps

\author{
Abbreviations \\ CAR Central African Republic. \\ DRC Democratic Republic of Congo. \\ Lep. Lepidoptera. \\ RES Resource persons. \\ $\mathrm{Sp}(\mathrm{p})$ Species.
}

\section{Background}

This study's purpose was to make an overview of how ants, bees, wasps, and their products, such as honey are utilized, perceived, and experienced in daily life across sub-Saharan Africa. This considering the need to consolidate stories,

Arnold van Huis

Arnold.vanhuis@wur.nl

1 Laboratory of Entomology, Wageningen University \& Research, Wageningen, The Netherlands cultures etc. scattered in songs, etc. across sub-Sahara Africa into a documented format that can be shared.

The number of insect species in the world is estimated to be $1,013,825$ while the number of species in the Hymenoptera is 117,000 (11.5\%) (Stork 2018) of which about 20,000 in the Afrotropical zone (WaspWeb 2020). The group of Hymenoptera that will be covered in this article are ants, bees, and wasps. They belong to the suborder Apocrita, characterized by a constriction between the first and second abdominal segments called a waspwaist (petiole). The number of species of ants and bees in the Afrotropical region is 1705 (Robertson 2000) and 2783 (Coetzer and Eardley 2019), respectively. In the wasp category, there are many families, which often could not be distinguished by my informants. Therefore, we dealt with the wasp families often found in houses: 1 . Vespidae (worldwide about 5000 species)(Pickett and Carpenter 2010), in particular, potter wasps of the subfamily Eumeninae; and 2. Sphecidae (worldwide 791 species) (Pulawski 2020), which are characterized by a very long, slender waste. 
The honey bee Apis mellifera (Hymenoptera: Apidae) seems to have 24 subspecies in Africa, corresponding to geographical or ecologically distinct regions (Hepburn and Radloff 1998). However, the classification into well-defined sub-species seems to be complex and for the purpose of this article, it is not relevant to go further in detail. The species occurs worldwide, but analysis of mitochondrial genomes of 18 A. mellifera subspecies supports a northern African or Middle Eastern origin (Tihelka et al. 2020).

Adult females of the solitary wasps in the families Vespidae and Sphecidae, capture prey that they paralyze with a sting (the venom acting as preservative) and place the prey in a closed-cell along with an egg (Delong 1960; Weseloh 2003). The larva that hatches feeds on the enclosed prey until fully developed. Species specialize on different prey and construct different kinds of cells. Sphecid wasps such as mud daubers build their mud nests in attics, carports, and porches (Akre and Reed 2002). These wasps are often clearly visible around nesting sites as they make frequent trips carrying mud to build their nests.

In this article, we often dealt with ants of the genus Dorylus, also called driver ants, safari ants, soldier ants, or siafu (Fig. 1). I will use the name 'driver ants' in this article. Dorylus spp. have the largest queen of all ants capable of laying 1 to 2 million eggs in a month. A colony such as those of Dorylus wilverthi, may have 22 million workers (Hölldobler and Wilson 1990). During migration, they form a bivouac, a nest that measures a meter across constructed out of the living ant workers' bodies to protect the queen and larvae and are later deconstructed as the ants move on. During their migratory phase, the ants set up bivouacs at new sites each night. In the morning, the bivouac dissolves into raiding columns that travel up to $20 \mathrm{~m}$ per hour with lead workers laying a chemical trail for other workers to follow.

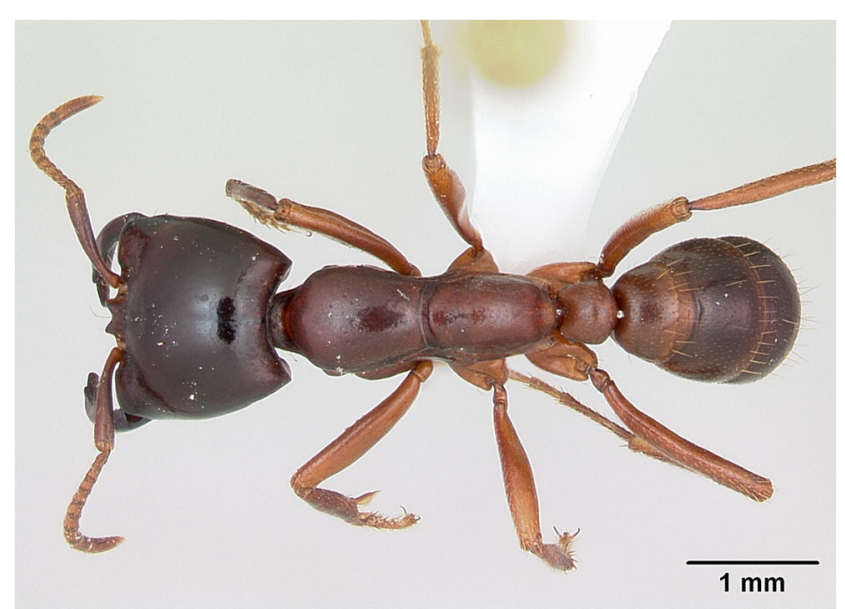

Fig. 1 Dorsal view of ant Dorylus gribodoi (Hymenoptera: Formicidae). Source: https://commons.wikimedia.org/wiki/File:Dorylus_gribodoi casent0172627_dorsal_1.jpg. Attribution: April Nobile/www.AntWeb. org
Smaller workers lead the column, while larger, formidable soldiers protect the flanks. They defend themselves fiercely when being attacked. They can wipe areas clean of insects and small mammals (Mahar 2016).

A part of the results dealing with medicine has been published in Van Huis (2002). Sometimes the boundary between medicine and superstition is not clear and arbitrary decisions are then made. Similar articles have been published that deal with the Isoptera (termites) (Van Huis 2017) and Lepidoptera (butterflies and moths) (Van Huis 2019).

\section{Methods}

The information was collected by reviewing the literature and personal interviews. The interviews were conducted in the years 1995 and 2000 in Africa and concentrated on the traditional, nutritional, and medical uses of arthropods and their products as well as on their role in religion, witchcraft, art, song, music, dance, children's games, mythology, and literature. This list was used to ask open questions in unstructured interviews to generate qualitative data. Although the information was collected some 20 years ago, the information is not only valid, but probably more difficult to be obtained now. This because of the rapid urbanization and the fact that older people often had to be consulted which is a sign that this type of information is rapidly disappearing. A part of the results obtained in 1995 on insects has been published (Van Huis 1996), as well as the part on edible insects over both years (1995 and 2000) (Van Huis 2003).

The total number of people interviewed was 304 from 27 different countries in sub-Saharan Africa of whom 22 were resource persons (experts without recorded ethnic affiliation) (Table 1). Of the 5 other respondents, the ethnic group was unknown. The total number of ethnic groups was 121, excluding Zanzibar and Madagascar where the ethnicities were not recorded. Names of ethnic groups were checked, mostly in Wikipedia (Wikipedia 2019) and the Joshua project (Joshua project 2019). This project coordinates the work of missionary organizations to highlight the ethnic groups of the world with the fewest followers of evangelical Christianity.

Most of the people interviewed were scientists or technicians trained in entomology. The interviewees were identified by visiting entomological groups of universities and (inter)national agricultural research institutes, plant protection services, museums, and crop protection projects. Most staff of these organizations were interviewed (often arranged by the responsible officers). The age of the persons interviewed varied between 25 and 65 . Most of the respondents were male reflecting the gender composition of the organizations. A few times people were interviewed in villages who had no entomological background. This proved to be a challenge because of language and confusion about the insect species. Twenty- 
Table 1 The number of respondents $(\mathrm{N})$ per country and ethnic group

\begin{tabular}{|c|c|c|c|}
\hline Country & Ethnic group - N & $\mathrm{RES}^{1}$ & $\mathrm{~N}$ \\
\hline Benin & Bariba-1, Fon-4, Goun-1, Nagot-6, Popo-1, Tori-1 & & 14 \\
\hline Burundi & Hutu-2 & & 2 \\
\hline Burkina Faso & Mossi-4, Fula-1 & & 5 \\
\hline Cameroon & $\begin{array}{l}\text { Bafia-1, Bakoko-1, Bakossie-1, Bamileke-14, Banen-1, Bani-Pahuin-1, Bassas-2, Beti-Eton-1, Beti-Ewondo-1, Bolous-1, } \\
\text { Matha-1, Tikar-1, Wimboum-1, Yambassa-1 }\end{array}$ & 2 & 28 \\
\hline $\mathrm{CAR}^{2}$ & Gbaya-1, Kari-1 & & 2 \\
\hline $\mathrm{DRC}^{3}$ & Mbochi-1, Teke-1 & & 2 \\
\hline Chad & Arabe-1, Goulaye-2, Kanembou-1, Mbaye-2, Ngambaye-7, Sara-Kaba-1, Sara-Niellim-1, Tupuri-1, Wadai-1 & & 17 \\
\hline Gambia & Jola-1, Mandinka-1 & & 2 \\
\hline Guinee-Bissau & Balanta-1 & & 1 \\
\hline Kenya & Kalenjin-1, Kamba-4, Kikuyu-2, Luo-4, Meru-1, Somalian- 1 & & 13 \\
\hline Madagascar & - & & 24 \\
\hline Malawi & Chewa-1 & & 1 \\
\hline Mali & Fula-1, Mande-Malinke-1, Mande-Mandinka-1, Sarakolé-1, Senufo-2, Songhay-3, Tuareg-1 & & 10 \\
\hline Mozambique & Bitonga-1, Makua-1, Nchope-1, Shona-1, Tsonga-Rhonga-2, Tsonga- Shangana-1, Tsonga-Tswa-1 & & 8 \\
\hline Namibia & Damara-1 & & 1 \\
\hline Niger & Djerma-1, Hausa-9, Kanuri-1, Songhai-4 & 1 & 15 \\
\hline Nigeria & Ebibio-1, Ebira-1, Yoruba-15, Unknown-1 & & 18 \\
\hline Rwanda & Kiga-Toro-1 & & 1 \\
\hline Senegal & Bainuk-1, Diola-4, Fula-1, Halpulaar-2, Lebu-1, Serer-3, Wolof-5 & & 17 \\
\hline South Africa & - & 6 & \\
\hline Sudan & $\begin{array}{l}\text { Dongolawi-1, Fula-1, Gaälien-3, Kambari-Abadi-1, Kawahla-1, Kuku-1, Mahas-1, Nubian-1, Nubian-Mahas-1, } \\
\text { Rubatab-2, Tunyur-1, unknown- } 4\end{array}$ & 5 & 18 \\
\hline Tanzania & Chaga-7, Digo-1, Iraqw-3, Iramba-1, Mwarusha-2, Pare-1, Rangi-1, Sukuma-2, Zanaki-1 & 1 & 19 \\
\hline Togo & Akebu-1, Ewe-5, Cotocoli-1, Kabye-1, Mina-1 & 3 & 9 \\
\hline Uganda & Acholi-1, Banyankole-1, Bunyoro-1, Busoga-1, Ganda-7, Langi-1, Luo-2, Nyoro-1 & & 15 \\
\hline Zambia & Bemba-1, Ila-1, Lovale-1, Lozi-2, Lunda-1, Namwanga-2, Nyanja- Chewa-1, Tonga-10, Tumbuka-1 & 2 & 20 \\
\hline Zanzibar & - & & 9 \\
\hline Zimbabwe & Ndebele-1, Shona-9, Zezuru-1 & 2 & 11 \\
\hline \multicolumn{2}{|c|}{ Total number of resource persons and respondents } & 22 & 282 \\
\hline
\end{tabular}

${ }^{1}$ Resource persons

${ }^{2}$ Central African Republic

${ }^{3}$ Democratic Republic of Congo

two of the respondents acted as resource persons on special subjects (for example experts on termites or insects as food or medicine) or had special positions (professors, heads of organizations, shamans, museum directors, and priests). In these cases, the ethnic origin of the person who provided the information was not considered relevant.

A list of issues was used to be covered in the interviews. Several respondents got this list before the country was visited. Often, they questioned elders, grandparents, family members, and acquaintances before my arrival. This information was then passed on to me. The respondent from rural areas had more information than those from urban areas.

Vernacular names and their meaning were double-checked with the respondents and most of the time by a literature search using web search engines, among which those that deal with scholarly literature. The national libraries and university libraries in London and Paris, the library of the African Studies Centre in Leiden, the Netherlands, and some libraries of the countries visited were consulted. The literature consulted was mainly of anthropological nature. Findings for a country or a certain tribe were only reported if the information was received from more than one respondent, or if the information given during interviews was confirmed in the literature. The respondents' countries and tribes are mentioned to specify the sources of information. They cannot be used for establishing correlations between ethnicity and information provided. The qualitative character of the information provided is emphasized. 


\section{Results and discussion}

\section{Which insects or their products are eaten?}

\section{Bees and honey}

Bee larvae are sometimes eaten together with the honey. Beer brewing from honey is common in Africa, but particularly in East Africa [Burundi: Hutu; Cameroon: Wimboum; GuineaBissau: Balanta; Kenya: Kalenjin (Ogutu 1986),Kamba, Kikuyu, Luo, Meru; Sudan: Kuku; Tanzania: Chaga, Iraqw, Mwarusha, Pare; Zambia: Bemba, Lozi, Tonga, RES].

\section{Ants}

The nutritious alates (queens) of the thief ant, also called black ant, Carebara vidua (Hymenoptera: Formicidae) (Fig. 2) are collected during their nuptial flight when these ants emerge in large numbers from the termitaries in which their nests are concealed (Bequaert 1921). Often, only the abdomens are eaten, either uncooked or roasted (Ayieko et al. 2012; Wheeler 1965). They are consumed in Kenya (Luo) (Ayieko et al. 2012), Uganda (Ganda and Nyoro), Zambia (Tonga, Nyanja, RES), and Zimbabwe (Shona), often by frying or roasting the abdomen. They emerge from holes near the termite hill and for preventing them to fly, the head is often crushed. The small ants (workers) are irritating as they come out from the holes at the same time. The females are over $2 \mathrm{~cm}$ long, while the tiny yellowish workers are less than $2 \mathrm{~mm}$ long. They build their nests in close association with the nests of termites on which they prey (Lepage and Darlington 1984).

Sugar ants (Camponotus spp.) are also eaten, mainly because it is difficult to remove them from the sugar, but at the same time it is believed that they are good for the stomach (Mozambique: Bitonga, Macua, Rhonga, Shangana), Zambia (Bemba, Luunda, Tonga, RES), and Zimbabwe (Ndebele,

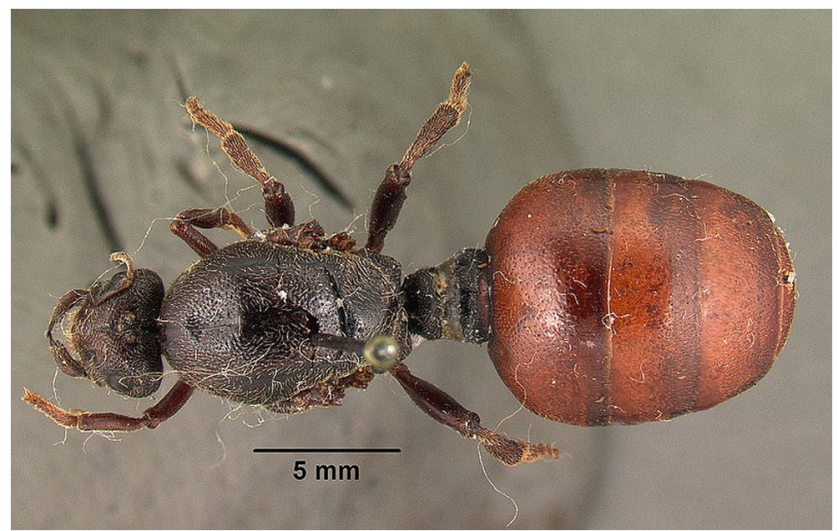

Fig. 2 Dorsal view of ant Carebara vidua (Hymenoptera: Formicidae). Source: https://commons.wikimedia.org/wiki/File:Carebara_vidua casent0101463_dorsal_1.jpg. Attribution: April Nobile. April Nobile $\overline{/}$ www.AntWeb.org
Shona). The San from the Kalahari in southern Africa, handcollect some Camponotus ants which are then pounded and mixed with salad, giving it a sweet-sour flavour, because of the formic acid (Nonaka 1996).

Weaver ants, a popular food in southeast Asia (Van Itterbeeck et al. 2014), are not eaten in Africa, except for turning sauces acid (CAR: Kari). Only the Bamileke in Cameroon mentioned that they eat the eggs of the driver ants.

\section{Wasps}

Larvae or adults of wasps are not eaten, except for their use as medicine. I only came across a story mentioned by the Hausa in Niger, that they break the wasp into two and that from the tube of the abdomen (either a sphecid wasp or a vespid wasp of the genus Belonogaster) they suck a sugary substance.

\section{Beneficial ants and wasps}

Driver ants clear the house of cockroaches, mice, snakes, scorpions, and termites (Cameroon: Bakossie, Bamileke, Bassas, Bolous, Beti-Ewondo; Kenya: Kalenjin, Kamba; Tanzania: Chaga, Iraqw, Mwarusha, Zanaki; Togo: Ewe). During the occupation, the occupants need to be absent. If you want snakes to come out of a hole, collected driver ant soldiers should be poured in (Nigeria: Yoruba). Contrary when ants are present it is believed that there are no snakes (Tanzania: Chaga). However, how to protect or clear your house and your animals from driver ants? To scare them off, fire was mentioned (Benin: Nagot; Nigeria: Yoruba), or spreading salt (Cameroon: Bamileke; Nigeria: Yoruba), ashes (Cameroon: Bakossie, Bamileke; Tanzania: Iraqw, Pare; Togo: Ewe), kerosine (Cameroon: Bakossie; Uganda: Ganda) or petrol (Cameroon: Bamileke, Banen).

In the north of Cameroun, the Mofu collect a thousand Dorylus soldier ants and put them in a calabash with leaves of Ficus abutilifolia. Using some rituals they release the ants in order to clear houses of termites such as Trinervitermes spp. from the straw of the roof, and Macrotermes subhyalinus from the sorghum stems protecting the walls, as well as snakes or other vermin (Seignobos 1999). They can even direct the driver ants utilizing an ochre (natural clay earth pigment) trail to parts of the house where infestations of vermin or termites are most severe.

Wasps in orchards prevent not only mango's being stolen (Cameroon: Banen; Mozambique: Changana; Tanzania: Sukuma), but they also protect bird nests being raided by egg poachers (Tanzania: Sukuma; Chad: Sara-Niellim; Zimbabwe: Shona).

People at the borders of the Sahara, such as the Tuareg, collect grass seeds from ant nests (Bernus 1999). This was also mentioned by informants from this region (Chad: Goulaye, Kanembou, Ngambaye, Tupuri; Mali: Songhai, 
Tuareg; Niger: Hausa, Songhai; Senegal: Wolof; Sudan: Gaälien, Mahas). One of those seeds is from Panicum turgidum, a stiff desert grass with smooth and solid stems (Irvine 1952). Also, the Nama people of southern Africa systematically and regularly collect from the stores of grass seeds collected by certain black ants.

\section{Medicine}

\section{Bees and honey}

In Sudan (Dongolawi, Kambari-Abadi, Kuku, Kawahla, Rubatab, RES) bee stings are widely used as a cure against rheumatic arthritis [see for a review of bioactivities of bee venom: Azam et al. 2019, Lee et al. 2014 and Aliyazicioglu 2019]. This is also practiced in other countries (Burkina Faso: Mossi; Mozambique: Shona; Tanzania: Mwarusha). In Benin, a powder or decoction of the bee Apis mellifera, mixed with certain plant species, is used against dizziness, tiredness, asthma, stomach-ache, and myopia (Loko et al. 2019).

\section{Honey}

The use of honey in medicine is very well known, as indicated by several review articles (Abeshu and Geleta 2016; Basa et al. 2016; Rana et al. 2018). To use honey as a medicine is a general practice in sub-Saharan Africa and was so recurrent in my interviews, that countries and ethnic groups need not be mentioned. In the Arabic and Islamic world, one has to take into account that the prophet Mohammed considered a drink of honey as one of the methods in curing an illness (AlRawi et al. 2017). It seems to cure most ailments and the following were mentioned: allergy, anaemia, chest pain (often with eggs), bad cough (used with lime), whooping cough, asthma, flu, high fever (as an ointment), influenza, tonsillitis, earache [also mentioned as a remedy in the Qur'an (Thanvi 2015; p. 89)], hiccup, tetanus, measles, as an ointment for dermatological problems (such as boils, sores, scabies, ulcers, leishmaniasis wounds, insect bites), jaundice, eye problems, cancer, epilepsy in Sudan (Mohammed and Babikir 2013), tiredness, stomach problems, (amoebic) dysentery, colic, constipation, diabetes, hypertension, palpitations, haemorrhoids, intestinal worms, poisoning (as antivenom), to purify the blood. Several times it was mentioned that it should be mixed with certain herbs. In Zanzibar, it is often mixed with raw eggs against cough. Besides curing health problems, it was also considered to prevent diseases and therefore used as a sweetener instead of sugar. It is also used as a carrier for other medicines. In West Africa, honey is often prescribed by marabouts (Muslim religious leader and teacher). It can also be used as a cosmetic (e.g. face masks by women), but also for cuts, scars, and (circumcision) wounds as an anti-septic. Very common is the use against burns, which frequently occurs as the use of open cooking fires in homesteads.

Honey can also be used as a stimulant: aphrodisiac, to obtain vital sperm, to facilitate child delivery, for babies who have difficulties in getting their teeth and for stimulating the intellect and the memory for babies and young children. Babies even during the first day of their lives, specifically in West Africa, receive a drop of honey in the mouth. In Nigeria (Yoruba), it is used at wedding ceremonies as dowry (e.g. beer from honey as marriage is as sweet as honey) and naming ceremonies (honey put in the mouth of babies). It was also several times mentioned that pregnant women should not take it as it provokes an abortion (Cameroon: Bamileke; CAR: Gbaya; Chad: Goulaya; Kenya: Kamba; Niger: Hausa; Sudan: Kuku;). It is also used as offers for the ancestors (Madagascar).

For all these uses of honey mentioned above, a pot of honey seems to be present in all African households.

\section{Bee wax}

Bee wax is used for closing holes in containers (Cameroon: Beti-Ewondo; Burundi: Hutu; Kenya: Kamba, Luo; Togo: Akebu; Zambia: Lovale, Tonga), for making candles (Cameroon: Bamileke; Zambia: Tonga) and for treating music instruments such as drums (DRC: Teke; Zambia: Luvale) hand pianos (Cameroon: Bamileke; Zambia: Tonga), and string instruments (Cameroon: Bamileke; Kenya: Luo). Bee wax in Sudan is used as a cosmetic, mixing it with sesame oil for the hair (Fulani, Mahas, RES) or the skin (Nubian; RES).

\section{Ants}

Weaver ants of the genus Oecophylla construct nests in trees by weaving together leaves using larval silk. In Australia and southeast Asia, these ants are used as biological control agents (Van Mele et al. 2002). But this was only once mentioned by one informant from Pemba Zanzibar, whose father used it. The African species is Oecophylla longinoda. It was mentioned mostly that it is used as an aphrodisiac (Cameroon: Bafia, Beti-Eton, Beti-Ewondo, Bamileke) and as medicine to cure asthma/cough (Cameroon: Bani-Pahuin; Zanzibar; Pemba), or rheumatism (Togo: RES), often by boiling the nest with ants and adding some medicinal plants. In Benin, a powder or concoction of Formica spp. with certain plants is used against ulcers, malaria, jaundice, enuresis, and memory loss (the last one also mixed with honey which is generally believed to stimulate memory) (Loko et al. 2019).

To cure children of about $4-5$ years old from bed-wetting, they are put in a disturbed ant nest (of Myrmicaria opaciventris); it seems to be more than just a punishment (Cameroon: Bamileke, Wimboum; Tanzania: Sukuma). The ants can also be put in the bed of the child (Cameroon: 
Bakossi; Zambia: Sekeseke, REF). To stimulate children to walk, the powder of crushed ants is smeared on scars made in the legs (Zambia: Tonga). When a baby receives a very painful bite by the ant species Brachyponera sennaarensis, the child will walk precociously (Cameroon: Bamileke).

When ants are going to where people have urinated, it is a sign that the person is diabetic (Zanzibar).

\section{Wasps}

Nests of the potter wasps are often used as a medicine, but several informants did not know for which problem (Mali: Minka; Niger: Huasa, Songhai; Tanzania: Iraqw; Togo: Ewe, Kabye). In Central and West Africa often the cure of mumps (a viral infection causing swelling of the salivary glands) was mentioned (Benin: Bariba, Fon, Goun, Nagot, Popo, Tori; Cameroon: Bafia, Bakossie, Bamileke, Bassas; Chad: Sara-Kaba: Nigeria: Yoruba; Togo: Ewe). The earthen nest is crushed, mixed with water and the paste is put on the cheeks of children. Not only in sub-Saharan Africa but also in the Amazon, this is practised by ethnic groups to relieve symptoms (killing pain and lowering fever)(Rodrigues et al. 2018). Minerals in the mud probably act as pharmaceuticals (Khurana et al. 2015). This probably also explains the practice for other problems such as rheumatism (Nigeria; Sudan: Kuku), quicker closing of the fontanel of babies (Togo: Cotocoli), throat infections (Mali: Sarakolé), sinusitis (Mozambique: Bitonga, Tsonga-Rhonga), boils, ulcers and other inflammations (Burkina Faso: Mossi; Cameroon: Bamileke; CAR: Kari; Togo: Ewe; Zambia: Tonga), and a headache (Mali: Tuareg; Mozambique: Shona). Like termite soil, it is also used as a plaster (Mali: Tuareg), see also van Huis (2017).

\section{Religion and superstition}

Social insects are sometimes used to ensure a successful marriage. For example, a husband is given a drink made from a wasp nest (Zambia: Nyanja). The wasp always returns to the nest, so it is believed that drinking the wasp concoction guarantees that the husband will come home.

\section{Bees}

When a swarm attacks people, it is generally believed that the bees have been sent by an enemy, often with the intent to kill somebody [Benin: Fon, Goun, Nagot, Popo; Burkina Faso: Mossi; Burundi: Hutu; Cameroon: Bamileke, Banen, BuluDoula, Matha; Chad: Goulaye; Mali: Songhai; Niger: Songhai; Nigeria: Ebibio, Yoruba, Unknown; Senegal: Diola, Serer; Rwanda: Kiga-Toro; South Africa: Xhosa Hirst 2005; Tanzania: Chaga, Mwarusha; Togo: Akebu, Ewe; Uganda: Ganda, Busoga; Zambia: Lunda, Tonga].
Witchdoctors are involved, either to send the bees if you wish to punish somebody or to find out what is wrong and what you should do to deal with the problem. In Cameroon, wild bees are sent to kill somebody who has sworn a false oath (Seyffert 1930; p. 166). The Sara-Niellim in Chad has an accused person to put the hand in a beehive and when not stung he is not considered to be guilty (Seyffert 1930; p. 116). In Senegal (Diola) for the independence of Casamance (Senegal) in 1980 (Williams 2020; p. 305), there was a rumour that all persons being allochthones would be attacked. Therefore, they advised the Diola to tie a red string around the wrist. Although everybody was wearing the red string the bees eventually were not sent. Bees are also applied in warfare [Cameroon: Bolous; DRC: Mbochi, Teke; Nigeria: Tiv (Dike and Onwuka 2016)], e.g. in Tchad when there was a war between the Moundang and the Foulbé or in Kenya when there was a fight between the Kamba and the Maasai.

When a swarm of bees comes to the house it is mainly perceived as a bad omen showing that a terrible thing is about to happen to the family [Cameroon: Bassas; Kenya: Luo; Nigeria: Ngwa (Dike and Onwuka 2016); Tanzania: Chaga, Mwarusha; Togo: Cotocoli]. However, some indicated that it could also be a sign of luck or richness (Kenya: Kikuyu; Tanzania: Chaga, Sukuma).

The arrival of single bee in the house who flies around somebody or which settles on somebody, is a sign of: 1) getting good news (Burkina Faso: Mossi; Cameroon: Bamileke; Chad: Goulaye; Madagascar; Mali: Mande-Malinke, Tuareg; Mozambique: Ronga; Niger: Hausa; Tanzania: Chaga, Iraqw, Digo, Mwarusha, Zanaki); 2) getting a visitor [Cameroon: Bamileke; Kenya: Kikuyu, Luo; Nigeria: Ibibio, Tiv - Dike and Onwuka 2016; Rwanda: Toro; Senegal: Bainuk; Tanzania: Iraqw; Uganda: Bunyoro, Ganda, Busoga, Nyoro; Zambia: Tonga; Zimbabwe: Shona, Zezuru]; 3) or an ancestor (Burkina Faso: Mossi).

It was regularly mentioned that one must be careful with perfume as this agitates bees (Niger: Hausa, Kanuri; Sudan: RES). Also Ehrhardt (2015) warned not to use perfumes and scented products that attract and agitates bees and wasps.

Several ethnic groups in sub-Saharan Africa have the bee as their totem (emblem of the group) (Seyffert 1930; p. 114), e.g. the Nandi in Kenya seems to be able to control the bees (Ransome 1986) or the Bakoanda in Zambia, who make beer from honey (Bodenheimer 1951; p. 182).

I bought from a witch doctor at a local market in Lomé Togo a fetish which contained the powder of a bee and wasp. This was put in a small fetish called "Woanyinou" in Fon (Fig. 3). While conducting some rituals you must put it in your house as an assurance of two people (husband and wife) staying together (probably because it concerns social insects). The use of the bee as a fetish (amulet) was also mentioned in Benin (Goun). 


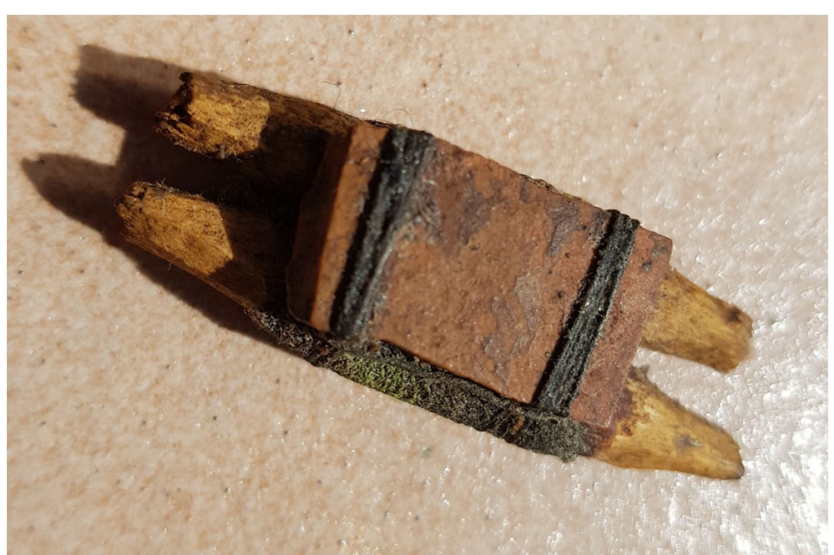

Fig. 3 The amulet "Woanyinou" (Benin: Fon) containing powder of a bee and wasp $(2.5 \times 1 \mathrm{~cm})$. Photo by the author

\section{Honey}

Honey is mentioned in the Qur'an mainly because of the many medicinal values (Purbafrani et al. 2014). Honey was mixed with ink in Islamic writings (Donaldson 2020; Meri 2006; p. 705), for example by writing the verses of the Qur'an in Arabic on boards. The ink is washed off when they have finished writing a new text on the board. Believers often drink the water used to wash the board as it brings spiritual and medicinal benefits. When it is about intelligence one should put honey in the water (Gambia: Madinka; Niger: Hausa, Kanuri, Songhai; Senegal: Halpulaar). This water with honey is called 'Nassi' (Dumestre and Touré 2007; p. 40) and according to an informant from Gambia, the water should always be mixed with honey. In burials, honey is put in graves or honey beer is used in ceremonies for ancestors (Madagascar) (Seyffert 1930; p. 111).

\section{Ants}

Ants or ant nests are very much associated with witchdoctors, in particular when one is bitten (Benin: Fon, Popo; Burkina Faso: Mossi; Cameroon: Bafia, Bamileke, Bolous; Niger: Hausa; Senegal: Diola; Togo: Ewe: Uganda: Ganda; Zanzibar). It is either that the ants are sent by witchdoctors to do harm or that they transform themselves into driver ants. The ant nests are also associated with devils or ancestors (Mali: Tuarag; Niger: Djerma), also to expel demons (Niger: Shonghai). Therefore, offers are made on the ant nest (Burkina Faso: Mossi; Mali: Senufo; Niger: Djerma; Togo: Cotocoli).

In Togo (Mina) driver ants are assumed to have been sent by somebody if they bite/eat a child left unattended in the shade. In Chapter 16 of the book, "Ants" by Hölldobler and Wilson (1990) reference was made by somebody in Ghana who was told of an incident in which driver ants killed a baby left beneath a tree while its mother tilled the family garden. From Togo (RES) I was also told that wild animals also fear the driver ants. There is a proverb by the Yoruba in Senegal "if they unite, ants can kill an elephant" (Korem and Abissath 2004; p. 17). Another proverb indicates that a witchdoctor can eat everything except a driver ant (Togo: RES).

Driver ants may be put on sensible places of the corps by witchdoctors as an ordeal to interrogate accused persons (Garnier and Fralon 1951; p. 190). Driver ants are also used during circumcision in which soldier ants are up on the penis and the men must stay firm and not scream (Kenya: Kalenjin Tugen, Kamba). For female circumcision, Garnier and Fralon (1951; p. 70) mentioned the use of ants.

Driver ants when coming to the house are considered a bad omen (Nigeria: Yoruba), e.g. a relative may die (Uganda: Busoga, Ganda, Nyoro; Zambia: Lozi) or a punishment (Kenya: Luo).

However, if you come across a trail of ants (driver ants or small ants), it may bring luck (Tanzania: Chaga) or fortune, in particular when they carry food or eggs (Chad: Goulaye; Tanzania: Iraqw; Togo: Akebu, Cotocoli; Zambia: Ila, Lunda, Namwanga, Tonga; Zimbabwe: Shona). In Nigeria (Tiv) when somebody encounters such an ant trail he will check whether they carry termites because then his journey will be fortunate (East 1965). In Zambia (Nkoya) when a hunter comes across a stink ant (Megaponera sp.) with booty, he knows he will soon bring back a lot of meat to the village (Silow 1983; p. 27). It may also be a sign that the rain is coming (Burkina Faso: Mossi; Kenya: Kalenjin; Zanzibar). In Tchad (Ngambaye) it was mentioned that when the winged ants come out, that fishing will be excellent.

It was also mentioned several times in Niger (Hausa, Songhai) and Sudan (Gaälien) that the rainbow (snake) comes out of an ant nest and obstructs the rain. Rainbows are often associated with stopping the rain, e.g. in Kenya by the Luhyia (Parrinder 1982; p. 77); this is a similar story told for termite mounds (Van Huis 2017).

Many of my informants in Madagascar mentioned a story of ants and snakes. The story goes that when a snake enters a hole in the ground that the ants narrow the opening such that the snake cannot escape. Then they feed the snake and when well-fed, they devour the snake. The story is confirmed by Anderson (2018; page 105) who indicated that the story is universally believed by the Malagasy. Missionaries apparently dissected ant nest to verify the story, however, they were not able to confirm or deny it. There is even a very early publication (Toy 1875), which tells this story and which stresses that the local population firmly beliefs in it. My informants indicated that it relates to the following endemic snakes: the blonde hognose snake, Leioheterodon modestus; and the Dumeril's boa or the Madagascar ground boa (Acrantophis dumerili). A recent scientific publication (Jono et al. 2019) may shed some light on the story. The ant Aphaenogaster swammerdami host the snake Madagascarophis colubrinus, in its nest without being attacked. The likely reason is that the 
snake feeds on the blindsnake Madatyphlops decorsei, which is specialized in feeding on termites and ants. So, the ant protects their colonies against this blindsnake through symbiosis with M. colubrinus, which the Malagasy also call "the ant's mother".

In general, when you have tiny ants in the house it is a good sign often in terms of money (Benin: Bariba, Nagot; Chad: Ngambaye; Mali: Songhai; Nigeria: Yoruba) while in Benin (Fon) associate this with twins and the ants are there to protect the house and one puts maize flour and red palm oil on their trail. Giving them grains is also a method to let them disappear (Senegal: Wolof).

The Bamileke in Cameroon practice "La Culte des Crânes," based on devotion to the skulls of ancestors (Dumas-Champion 1989). Descendants must fulfil traditional duties with the ancestral skull, as ancestors can help descendants or punish them with illness or other misfortunes. One of my Bamileke informants from Cameroon told me that after five years they dig the skulls out and put them in a special house. Rituals are carried out, among which is the use of palm oils which is poured over the skulls. It is considered a bad sign if the oil is not removed by ants (likely Myrmicaria opaciventris).

In Cameroon, a driver ant (Dorylus spp.) called "Jaglavak" is considered by the Mofu to be the chief of the Mandara Mountains of northern Cameroon, while other ants constitute "local chiefs" (Seignobos 1999; Seignobos et al. 1996). While the panther and the Mofu chief are one and the same, the Jaglavak held the role of "prince of insects." A sub-ethnic group of the Mofu, the Movo, because of an ancient alliance, are like the Jaglavak and are feared for their power to harm. The ant is believed to aid the Movo in times of trouble, including cleaning up their compounds by chasing out vermininfested dwellings.

\section{Wasps}

One mixes the ground up wasp or the nest with larvae in dog feed in order to make him more vicious (Burkina Faso: Mossi; Kenya: Kamba; Mozambique: Nchope, Tsonga-Changana; Rwanda: Toro; Uganda: Bunyoro, Ganda, Nyoro). Also, it is believed that when a ground wasp is put on scars on the fist (Zambia: Lozi, Tonga; Zimbabwe: Ndebele, Shona, Zezuru) or to rub a wasp or the nest between the hands (Burkina Faso: Mossi; Niger: Hausa; Zambia: Lovale, Namwanga; Zimbabwe: Shona), that one can hit somebody hard.

Women use wasp nests (in a drink) when they cannot become pregnant or when wanting to prevent abortion (Togo: Ewe; Zambia: RES), to facilitate delivery (Zimbabwe: Shona) or against menstrual pain (Togo: Res).

In Madagascar, it was generally considered that when a dauber wasp starts constructing his nest in the house that this is a good sign such as a wife becoming or being pregnant (also mentioned in Burundi: Hutu), richness and prosperity. Informants from several other countries mentioned that you should leave a wasp nest in the house, as it protects the house and the owner against evil persons and witches (Senegal: Bainuk, Diola; Cameroon: Bamileke, Bassas, Bolous; DRC: Mbochi; Tanzania: Iraqw). However, for other ethnic groups in the different countries, the information was very contradictory: some leave the nests as a sign of prosperity and others remove them as it is considered a bad omen.

\section{Tales, proverbs and art}

\section{Bees}

One of the myths about honey by the Maasai is: When God gave cattle to man, the first woman, Naiterogob, gave birth to their first child, the son Sindillo, who later helped his father in keeping the cattle. One day, when looking at a bee swarm in a hollow tree, the son discovered the honey and brought it to his fathers' kraal. Since then honey is food for the Maasai (Seyffert 1930; p. 110).

In Nigeria, practically all the 200.000 traditional healers use honey in some of their medical preparations. This is rooted in the cultural history of the people. The medicinal and spiritual value of honey can be found in the spiritual literature called 'Ifa' (Kolawole 1997). The honeybee was sent by God from heaven to this earth. When the bee did not produce 'children' in the town Ile-Igbon she went to a place called Shaki where she found many trees with holes in it. She settled in one of them and laid eggs. When the population increased, they swarmed to other trees and from there to other places of the earth. The second chapter of 'Ifa' is called 'Oyeke meji' and an excerpt:

\section{They were coming from heaven for a life on earth \\ They all feared the eminence of disease and infirmity on earth \\ They were asked to make rituals of appeasement and sacrifice \\ On getting to the earth \\ They were all free from disease and infirmity \\ As they were dancing in the home of Oyin (bee) \\ They were drumming in the house of Ado (a type of bee) \\ The home of Fuun-Fuun (another type of bee) was not \\ less joyous \\ Who does not know that the home of the bee is never bitter?}

No one puts honey in the mouth and frowns.

The different San people from southern Africa all have different creation myths but always the praying mantis plays an important role (Leeming 1937; p. 75) such as in this story: Mantis was sent to find the purpose of life when the earth was 
covered with water and asked the bee to guide and carry him. However, Mantis was heavy and finally, he put Mantis in the heart of a white flower. The bee planted the first seed of a human being in Mantis and then died. This was the story of the birth of the first San (Anonymous 2020).

Proverbs dealing with bee or honey:

- 'His words are as sweet as honey (hassel), but his deeds are like the smell of onions (Bassel)', so it rhymes for the Mahas in Sudan.

- "A newly born baby is given honey and Aloë in order to make it realize to meet both with sweet and bitter experiences in life" (Swahili) (Farsi 1999; p. 37)

- "The bee does not have two stings" (Kenya: Kikuyu) (Barra 1991; p. 91). Greedy people always want more.

- "Leave some honey for the honey bird who led you to it." (South Africa: Zulu) (Korem and Abissath 2004; p. 55). This bird is called "the greater honeyguide, Indicator indicator (Piciformes: Indicatoridae), only occurring in sub-Saharan Africa and which leads human honeyhunters to wild bees' nests (Spottiswoode et al. 2016). This is to ensure that the bird can eat the eggs, larvae, and pupae and even wax (one of the few birds that can digest wax) left behind by the humans. Honey hunters always leave some honey for the honey bird. The bird is also mentioned by Seyffert (1930; p. 24) and even encountered by Livingstone (2001 p. 216) in 1855.

- "A little idleness caused the ruin of beehive" (Korem and Abissath 2004; p. 67). The Kikuyus hang beehives in the crowns of trees, but when you do not check-in time, the unattended beehive loaded with honey may fall and the honey is lost.

\section{Ants}

In Benin, Nigeria, James Inneh, seventy-nine years old, formerly a businessman, was in 1962, named commander of the royal guards, "isienwenro", by the king Akenzua. "Asako no s'oghionba" (ants sting the King's enemies), was how the royal guards responsible for the King's security, were called. During some rituals, they glide around the souverain, completely enveloping him like an army of ants (http:// leconcurrent.over-blog.com/article-african-kings-47033015. html).

Some proverbs dealing with ants from different countries:

- "It is not possible for the soldier driver ant to put on the trousers of a giant, but it is possible for the soldier driver ant to remove the trousers of a giant". Small things can cause severe damage (Nigeria: Yoruba).

- "I came across a long chain on the road but could not pick it up" (driver ants) (Swahili saying) (Farsi 1999)

\section{Wasps}

There are many stories about why the wasps have such a slender waist (see also the information given in the background) (Fig. 4) and why they cannot reproduce. People seem to associate this with their incapacity to reproduce (Cameroon: Beti-Eton; Chad: Ngambaye, Mbaye; Uganda: Luo, Ganda). One is that the wasp had a normal waist, but when many people passed on the road talking, he came out of the nest and placed his hands on his hips watching all this. He did it so long that his abdomen became constricted (almost two parts) (Nigeria: Yoruba). Another story from Senegal (Wolof) and Gambia: Jola. Mandinka) mentions that God was putting the soul in living beings and asked everybody to close the eyes during the event. But the wasp did not, reason that God took a rope and restricted the waist as a curse, so they could not get children anymore. Also mentioned by Ferry (1980) in Senegal (Bedik, Mandinka) for the potter wasp Delta emarginatum. Therefore, the wasp must transform the insects brought to the nest to young wasps. Also, In Sudan (Rubatab) the restricted waist was mentioned as the cause of not being able to give birth, and that God, therefore, has given them as compensation the ability to collect caterpillars which can be transformed in wasps. In Burundi (Hutu) I was told that the wasp wanted to see the king, but the king refused, and the wasp started a hunger strike, reason that she is so thin. In Uganda: Bunyoro, Ganda, Nyoro) the resemblance with a wasp is also made when one adopts a child (not being able to have children of their own). In Uganda (Langi) there is also a story, that there was a feast in heaven. They had to fly and so the winged ones had to take the unwinged ones. So, the wasp got the elephant, but the weight of the elephant was so much that it caused the waste of the wasp to become restricted. The

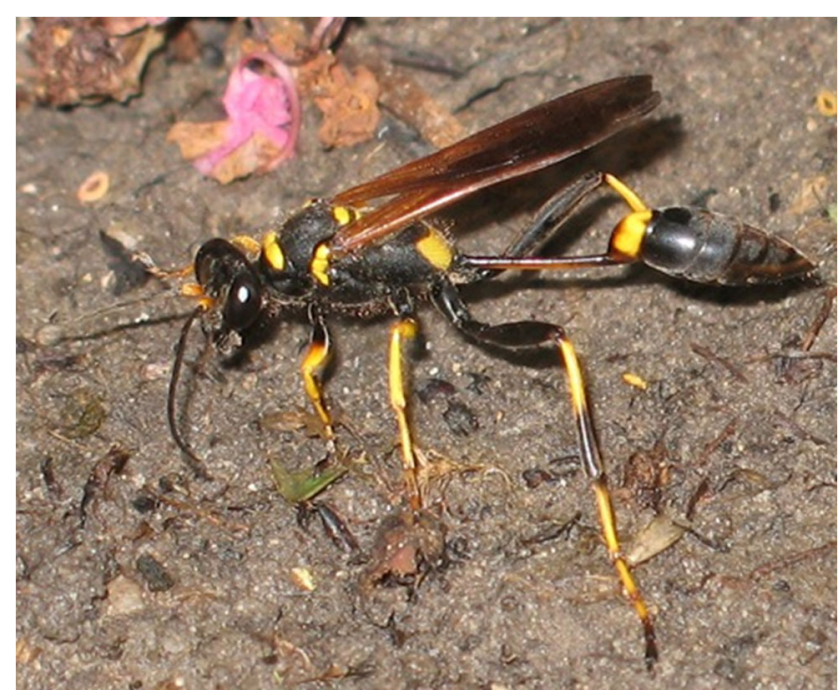

Fig. 4 A wasp, a mud dauber, Sceliphron sp. (Hymenoptera: Specidae) with the narrow waste. Source: https://commons.wikimedia.org/wiki/ File:Sceliphron-mud-dauber.jpg. Attribution: psionicman. Licensed under the Creative Commons Attribution 2.0 Generic license 
Bamileke in Cameroun [often mentioned that when parents are too occupied with their children: that they are like wasps, meaning that the children receive all the food they need but that the parents suffer (very thin)]. They (and the Toro in Rwanda) also call beautiful thin ladies, wasps.

There is a story of the Ila people from Zambia dealing with the mason wasp bringing fire from heaven (Allan 1999; p. 47; Parrinder 1982; pp. 29-30). The birds and insects discussed how to get fire from heaven. So, a vulture, a fish eagle, and a crow volunteered. However, only the mason wasp survived and rested after 30 days on a cloud. God observed and took pity on him, gave him fire, and told him to always build a house for his children near a fireplace, leave the eggs and return after several days to observe that the eggs change into wasps.

In Chad (Sara-Niellim) a story was told that the bee is intelligent and that the wasp talks too much. The wasp did not have the patience to listen to the bee how he constructs the hive. The wasp only said, yes, I know. Therefore, the wasp knows how to construct a nest, but not how to collect honey. This to indicate people who do not have the patience to listen to somebody.

A proverb from the Fulani in Senegal: "The children do not exactly look like their parents, but they have their personality" (Cabakulu 1992). This corresponds with the story from Senegal at the beginning of this paragraph in which caterpillars are transformed in wasps.

\section{Art}

In South Africa, there are many rock paintings depicting the activities of Stone Age honey hunters that have recently been discovered and recorded, depicting bees, honeycombs, and bees' nests or hives (Pager 1973). Ladders were used and one shows a man with a bag on his shoulder climbing towards a cavity or nest from which many bees are flying.

In Cameroon (Bamileke, Beti-Eton) it was mentioned that Oecophyla ants are used by young girls to perform better the traditional dance.

In DRC (Mbochi), and Nigeria (Yoruba) children trap a bee or bumblebee, put it in a matchbox. When moving the box, the bee makes a buzzing sound, like music.

When San children from the central Kalahari caught a winged driver ant (Dorylus sp.), they put a twig in the anus and by the movements of the ant with its wings sing "let us take of the sister's skirt and drink her urine together" (Nonaka 1996).

\section{Conclusions}

The consumption of insects from Hymenoptera is mainly confined to that of the queen of the chief ant, Carebara vidua.
This insect is eaten purposely, while other hymenopterous insects may be eaten but less intentional such as bee larvae in honey or small ants in sugar, mainly because they are difficult to remove.

Bee stings in Sudan are used for arthritis problems, as the venom seems to have bioactive properties. Honey is eaten all over sub-Saharan Africa, but the purpose of consumption is mostly medical (for numerous ailments), but it is also used for its stimulating properties (e.g. improving memory), and in ceremonies. Bee wax is used as a cosmetic and for treating drums or strings of musical instruments. The relation between Islam and honey is shown for example by drinking a mix of honey and ink, with which religious texts are washed off from wooden boards. The medicinal action of honey is not only a traditional practice but has been proven in many scientific articles. In central and West Africa the use of wasp nest to cure mumps is very common, but also used in the rest of Africa for other inflammations and this could be due to pharmaceuticals present in the mud of the ant nest.

I did not compare the medicinal uses of these insects and their products with other parts of the world. However, the reference to medical uses of ants, bees, and wasps, can be found in review articles (Costa-Neto 2005; Meyer-Rochow 2017), dealing with certain countries such as Brazil (Alves et al. 2012; Costa Neto and Pacheco 2005), India (Dutta et al. 2016; Zimian et al. 2005), China (Feng et al. 2009), Japan (Mitsuhashi 2002) and the Republic of Korea (Pemberton 2005) or concentrating on certain insects such as termites (Figueirêdoet al. 2015) and stingless bees and honey (Rao et al. 2016).

It is very difficult in traditional medicine to know whether a curative action is medical or whether a nonspecific psychological therapeutic effect of the substance or procedure (placebo effect) is involved. The distinction made in this chapter is arbitrary. The doctrine of signatures (similia similibus curantur - let likes be cured by likes) may be involved such as using fast-running ants to encourage babies to walk or using painful stinging wasps to make a guard dog more vicious. It is also often difficult to know what is behind a widely believed story, such as the ants trapping a snake in Madagascar, but in this case, a scientific explanation is provided.

Interesting is the behaviour or the appearance of the wasp which brings people to construct stories around it. One is that people see wasps bringing caterpillars to their nest and see emerging wasps afterward, leading to stories about the sterility of the wasps, also expressed in proverbs. Or the very narrow waste of certain wasps which people try to explain by creating stories of how this happened.

Also, believes may not be the same all over Africa, such as whether a wasp nest in the house should be considered a good or bad omen. The same is true for a bee swarm entering the house, although when individual bees are entering a house it is generally considered a good omen. Bee swarms are feared all 
over Africa as they may have been sent by witchdoctors or people as a punishment. The same is true for the very much feared driver ants.

Ants, bees, and wasps are social insects and as such maybe employed to stimulate cohesion between people (such as between husband and wife).

The article shows that the appearance and characteristics of these insects are an inspiration for many stories, such as the narrow waist of the wasp. Also, it has been the inspiration to create proverbs that have an educational purpose.

Acknowledgements I gratefully acknowledge all the people who generously shared their knowledge with me.

Author's contributions The author is responsible for all parts of this paper. He conducted all the interviews personally, reviewed the literature, analysed the data, and wrote the results.

Funding The funding for the study was provided by Wageningen University and Research.

Data availability The data that support the findings of this study are available from the author upon reasonable request. All data relating to the Hymenoptera generated or analysed during this study are included in this published article.

\section{Declarations}

Conflict of interests/competing interests The author declares that he has no competing interests.

Ethics approval Not applicable.

Consent to participate Interviewees agreed to participate.

Consent for publication Not applicable.

Code availability Not applicable.

Open Access This article is licensed under a Creative Commons Attribution 4.0 International License, which permits use, sharing, adaptation, distribution and reproduction in any medium or format, as long as you give appropriate credit to the original author(s) and the source, provide a link to the Creative Commons licence, and indicate if changes were made. The images or other third party material in this article are included in the article's Creative Commons licence, unless indicated otherwise in a credit line to the material. If material is not included in the article's Creative Commons licence and your intended use is not permitted by statutory regulation or exceeds the permitted use, you will need to obtain permission directly from the copyright holder. To view a copy of this licence, visit http://creativecommons.org/licenses/by/4.0/.

\section{References}

Abeshu M, Geleta B (2016) Medicinal uses of honey biology and medicine 8:279. https://doi.org/10.4172/0974-8369.1000279.
Akre RD, Reed HC (2002) 19 - ants, wasps, and bees (Hymenoptera). In: Mullen G, Durden L (eds) Medical and veterinary entomology. Academic Press, San Diego, pp 383-409. https://doi.org/10.1016/ B978-012510451-7/50021-9

Aliyazicioglu R (2019) Therapeutic effects of bee venom. Chem Sci Int J 26:1-5

Allan T (1999) Stemmen van de voorouders: Afrikaanse mythen. Time Life Books, Amsterdam

AlRawi SN, Khidir A, Elnashar MS, Abdelrahim HA, Killawi AK, Hammoud MM, Fetters MD (2017) Traditional Arabic \& Islamic medicine: validation and empirical assessment of a conceptual model in Qatar. BMC Complement Altern Med 17:157. https://doi.org/ 10.1186/s12906-017-1639-x

Alves RRN, ROdS N, DMdBM T, JEdL B, Barros AT, TLP D (2012) Traditional uses of medicinal animals in the semi-arid region of northeastern Brazil. J Ethnobiol Ethnomed 8:41

Anderson T (2018) Reassembling the strange: naturalists, missionaries, and the environment of nineteenth-century Madagascar. Lexington Books, Lanham

Anonymous (2020) The First Bushman / San. Tales and stories from Chrigi-in-Africa, ranger of the San Clan. http://www.gatewayafrica.com/stories/The_First_Bushman_San.html (consulted 1 October 2020)

Ayieko MA, Kinyuru N, Ndong’a MF, Kenji GM (2012) Nutritional value and consumption of black ants (Carebara vidua smith) from the Lake Victoria region in Kenya. Adv J Food Sci Technol 4:39-45

Azam MN, Ahmed MN, Biswas S, Ara N, Rahman MM, Hirashima A, Hasan MN (2019) A review on bioactivities of honey bee venom. Annu Res Rev Biol 30:1-13. https://doi.org/10.9734/ARRB/2018/ 45028

Barra G (1991) 1000 kikuyu proverbs (with translations and english equivalents). Kenya Literature Bureau, Nairobi

Basa B, Belay W, Tilahun A (2016) Review on medicinal value of honeybee products: Apitherapy. Biol Med 8:2. https://doi.org/10.4172/ 0974-8369.1000279

Bequaert J (1921) Insects as food. How they have augmented the food supply of mankind in early and recent years. Nat Hist Journ Amer Mus Nat Hist 21:191-200

Bernus E (1999) Graines sauvages Encyclopédie berbère, document G69 https://journals.openedition.org/encyclopedieberbere/1773?lang=en (consulted 1 October 2020)

Bodenheimer FS (1951) Insects as human food; a chapter of the ecology of man. Dr. W. Junk, Publishers, The Hague

Cabakulu M (1992) Dictionnaire des proverbes Africains. Editions l'Harmattan, Paris $304 \mathrm{pp}$

Coetzer W, Eardley C (2019) Insights into 260 years of taxonomic research gained from the catalogue of Afrotropical bees. Afr Invertebr 60:291-318. https://doi.org/10.3897/AfrInvertebr.60.37752

Costa Neto EM, Pacheco GM (2005) Utilização medicinal de insetos no povoado de Pedra Branca, Santa Terezinha, Bahia, Brasil (Medicinal use of insects in the county of Pedra Branca, Santa Terezinha, Bahia, Brazil). Biotemas 18:113-133

Costa-Neto EM (2005) Entomotherapy, or the medicinal use of insects. J Ethnobiol 25:93-114

Delong DM (1960) Man in a world of insects. Ohio J Sci 60:193-206

Dike ON, Onwuka E (2016) Entrepreneur perception and growth of beekeeping in Abia state, Nigeria. Int J Phys Hum Geogr 4:1-11

Donaldson BA (2020) The koran as magic. https://www.answeringislam.org/Quran/Magic/magic.htm (consulted 1 October 2020)

Dumas-Champion F (1989) Le mort circoncis. Le culte des crânes dans les populations de la Haute Bénoué (Cameroun / Nigeria). Systèmes de pensée en Afrique noire 9:33-73. https://doi.org/10.4000/span. 1114

Dumestre G, Touré S (2007) Maléfices et manigances, chroniques maliennes. Editions Karthala, Paris 
Dutta L, Ghosh SS, Deka P, Deka K (2016) Terrestrial edible insects and their therapeutic value in Moridhal Panchayat of Dhemaji district, Assam, Northeast- India. Int J Fauna Biol Stud 3:11-14

East R (1965) Akiga's story: the Tiv tribe as seen by one of its members. Oxford University press, London (first published in 1939)

Ehrhardt C (2015) Bites: ants, arhropods and wasps. In: Colyar MR (ed) Advancing practice: nursing procedures. FA Davis Company, Philadelphia, pp 20-24

Farsi SS (1999) Swahili sayings from Zanzibar. Vol. 1. Proverbs (52 pp), and volume 2 . Riddles and superstitions (37 pp). Kenya literature bureau, Nairobi

Feng Y, Zhao M, He Z, Chen Z, Sun L (2009) Research and utilization of medicinal insects in China. Entomol Res 39:313-316

Ferry MP (1980) Principaux invertebres connus des populations du departement de Kedougou (Senegal). Bulletin de l'IFAN, T 42, ser B, no 3, pp 502-523. https://pascal-francis.inist.fr/vibad/index.php? action=getRecordDetail\&lang=en\&idt=12345115

Figueirêdo RECR, Vasconcellos A, Policarpo IS, Alves RRN (2015) Edible and medicinal termites: a global overview. J Ethnobiol Ethnomed 11:29. https://doi.org/10.1186/s13002-015-0016-4

Garnier C, Fralon J (1951) Le fetichisme en Afrique Noire (Togo Cameroun). Payot, Paris, 213 pp

Hepburn HR, Radloff SE (1998) Honeybees of Africa. Springer Verlag, Berlin, p 35

Hirst M (2005) Dreams and medicines: the perspective of Xhosa diviners and novices in the eastern cape, South Africa. Indo-Pacific J Phenomenol 5:1-22

Hölldobler B, Wilson EO (1990) The ants. Mass Harvard University Press, Cambridge https://www.antwiki.org/wiki/The_Ants

Irvine FR (1952) Supplementary and emergency food plants of West Africa. Econ Bot 6:23-40

Jono T, Kojima Y, Mizuno T (2019) Novel cooperative antipredator tactics of an ant specialized against a snake. R Soc Open Sci 6: 190283. https://doi.org/10.1098/rsos.190283

Joshua project (2019) Countries. https://joshuaproject.net/countries/. Accessed 1 October 2020

Khurana IS, Kaur S, Kaur H, Khurana RK (2015) Multifaceted role of clay minerals in pharmaceuticals Future Sci OA 1:FSO6-FSO6. https://doi.org/10.4155/fso.15.6

Kolawole K (1997) Medicinal value of honey in Nigeria. In: Sommeijer MJ, Beetsma J, boot WJ, Robberts EJ, and De Vries R. (eds) perspectives for honey production in the tropics, proceedings of the symposium organised by the Netherlands expertise Centre for Tropical Agricultural Resources (NECTAR) held in Utrecht, 18 December 1995, pp 138-148

Korem AK, Abissath MK (2004) Traditional wisdom in African proverbs: 1915 proverbs from 40 African countries publishing trends ltd, Accra

Lee JA, Son MJ, Choi J, Jun JH, Kim J-I, Lee MS (2014) Bee venom acupuncture for rheumatoid arthritis: a systematic review of randomised clinical trials. BMJ Open 4:e06140. https://doi.org/ 10.1136/bmjopen-2014-006140

Leeming DA (1937) Creation myths of the world: an encyclopedia. ABCCLIO, Santa Barbara

Lepage MG, Darlington JPEC (1984) Observations on the ant Carebara vidua F. Smith preying on termites in Kenya. J Nat Hist 18:293-302

Livingstone D (2001) Missionary travels and researches in South Africa including a sketch of sixteen years' residence in the interior of Africa, volume II. The Narrative Press, London

Loko LEY, Medegan Fagla S, Orobiyi A, Glinma B, Toffa J, Koukoui O, Djogbenou L, Gbaguidi F (2019) Traditional knowledge of invertebrates used for medicine and magical-religious purposes by traditional healers and indigenous populations in the plateau department, Republic of Benin. J Ethnobiol Ethnomed 15:66. https://doi.org/10. 1186/s13002-019-0344-x
Mahar R (2016) Effect of varied disturbance types on Dorylus (Anomma) molestus defensive behavior in the West Usumbara Mountains, Tanzania Independent Study Project (ISP) Collection 2349. https:// digitalcollectionssitedu/isp_collection/2349

Meri JW (2006) Medieval Islamic civilization: an encyclopedia, volume 1. Routledge, New York

Meyer-Rochow VB (2017) Therapeutic arthropods and other, largely terrestrial, folk-medicinally important invertebrates: a comparative survey and review. J Ethnobiol Ethnomed 13:9. https://doi.org/10. 1186/s13002-017-0136-0

Mitsuhashi J (2002) Traditonal entomophagy and medicinal use of insects in Japan. In: Motte-Florac E, Thomas JMC (eds) Les Insectes dans la tradition oral. Peeters-SELAF, Paris, pp 357-365

Mohammed IN, Babikir HE (2013) Traditional and spiritual medicine among Sudanese children with epilepsy. Sudan J Paediatr 13:31-37

Nonaka K (1996) Ethnoentomology of the central Kalahari san. Afr Study Monogr (Supplementary Issue) 22:29-46

Ogutu MA (1986) Sedentary hunting and gathering among the Tugen of Baringo District in Kenya. Sprache und Geschichte in Afrika 7:323338

Pager H (1973) Rock paintings in southern Africa showing bees and honey hunting. Bee World 54:61-68

Parrinder G (1982) African mythology library of the world's myths and legends. Mandarin Offset, Hong Kong

Pemberton RW (2005) Contemporary use of insects and other arthropods in traditional korean medicine (hambang) in South Korea and elsewhere. In: Paoletti MG (ed) Ecological implications of minilivestock: potential of insects, rodents, frogs and snails, science publishers. Inc. Enfield, New Hampshire, pp 459-474

Pickett KM, Carpenter JM (2010) Simultaneous analysis and the origin of eusociality in the Vespidae (Insecta: Hymenoptera). Arthropod Syst Phylogeny 68:3-33

Pulawski WJ (2020) Catalog of Sphecidae sensu lato (= Apoidea excluding Apidae) http://researcharchive.calacademy.org/research/ entomology/entomology_resources/hymenoptera/sphecidae/ number of species.pdf (consulted 1 October 2020)

Purbafrani A, Hashemi SAG, Bayyenat S, Moghaddam HT, Saeidi M (2014) The benefits of honey in holy Quran. Int J Pediatr 2(supplement 5):67-73

Rana S, Mishra M, Yadav D, Subramani SK, Katare C, Prasad G (2018) Medicinal uses of honey: a review on its benefits to human health. Prog Nutr 20:5-14

Ransome HM (1986) Chapter I. early times, chapter 22. Primitive peoples of today. In: Hilda M, Ransom HM (eds) The sacred bee in ancient times and folklore. BBNO (Bee Books New \& Old), Bridgwater, pp 285-300

Rao PV, Krishnan KT, Salleh N, Gan SH (2016) Biological and therapeutic effects of honey produced by honey bees and stingless bees: a comparative review. Rev Bras 26:657-664. https://doi.org/10.1016/ j.bjp.2016.01.012

Robertson HG (2000) Afrotropical ants (Hymenoptera: Formicidae): taxonomic progress and estimation of species richness. J Hymenopt Res 9:71-84

Rodrigues E, Lago JHG, Santos JFL, Bitencourt ALV (2018) Nests of "caba-leão" wasps (Sceliphron sp., Sphecidae) used in traditional medicine by riverine communities of the Jaú and Unini Rivers, Amazon, Brazil: ethnopharmacological, chemical and mineralogical aspects. Rev Bras 28:352-335. https://doi.org/10.1016/j.bjp.2018. 04.005

Seignobos C (1999) Jaglavak, prince des insectes chez les Mofu du NordCameroun. In: Baroin, C. and Boutrais J (eds) L'homme et l'animal dans le bassin du lac Tchad. Actes du colloque du reseau MegaTchad. Orleans 15-17 octobre 1997, Editions IRD, Paris, pp 299 304

Seignobos C, Jean-Philippe D, Henri-Pierre A (1996) Les Mofu et leurs insectes. J Agric Tradit Bot Appl 38:125-187 
Seyffert C (1930) Biene und Honig im Volksleben der Afrikaner, mit besonderer Beruecksichtigung der Bienenzucht, ihrer Entstehung und Verbreitung. R Voigtlaenders Verlag, Leipzig

Silow CA (1983) Notes on Ngangela and Nkoya Ethnozoology. Ants and termites Etnologiska studier 36, Goeteborg, $177 \mathrm{p}$

Spottiswoode CN, Begg KS, Begg CM (2016) Reciprocal signaling in honeyguide-human mutualism. Science 353:38-389. https://doi. org $/ 10.1126 /$ science.aaf 4885

Stork NE (2018) How many species of insects and other terrestrial arthropods are there on earth? Annu Rev Entomol 63:31-45

Thanvi HMAA (2015) Remedies from the holy Qur'aan: an abridged translation of A'maale Qur'aani https://issuu.com/cosmologer/ docs/remedies-from-the-holy-quran-by-sha (consulted 1 October 2020)

Tihelka E, Cai C, Pisani D, Donoghue PCJ (2020) Mitochondrial genomes illuminate the evolutionary history of the Western honey bee (Apis mellifera). Sci Rep 10:14515

Toy R (1875) Ants and serpents The Antananarvio Annual and Madagascar Magazine 1:125. https://tinyurl.com/y6h4rnup

Van Huis A (1996) The traditional use of arthropods in sub Saharan Africa. The Netherlands entomological society (N.E.V.), Amsterdam, pp 3-20

Van Huis A (2002) Medical and stimulating properties ascribed to arthropods and their products in sub-Saharan Africa. In: Motte-Flora E, Thomas JMC (eds) Les insectes dans la tradition orale - insects in oral literature and tradition. Peeters-SELAF, Paris, pp 367-382

Van Huis A (2003) Insects as food in sub-Saharan Africa. Insect Sci Appl 23:163-185

Van Huis A (2017) Cultural significance of termites in sub-Saharan Africa. J Ethnobiol Ethnomed 13:8. https://doi.org/10.1186/ s13002-017-0137-z
Van Huis A (2019) Cultural significance of Lepidoptera in sub-Saharan Africa. J Ethnobiol Ethnomed 15:26. https://doi.org/10.1186/ s13002-019-0306-3

Van Itterbeeck J, Sivongxay N, Praxaysombath B, Van Huis A (2014) Indigenous knowledge of the edible weaver ant Oecophylla smaragdina Fabricius Hymenoptera: Formicidae from the Vientiane plain, Lao PDR. Ethnobiol Letters 5:4-12

Van Mele P, Cuc NTT, Van Huis A (2002) Direct and indirect influences of the weaver ant Oecophylla smaragdina on citrus farmers' pest perceptions and management practices in the Mekong Delta, Vietnam. Int J Pest Manag 48:225-232

WaspWeb (2020) Wasps, bees and ants of Africa and Madagascar WaspWeb. http://waspweb.org/Afrotropical_wasps/index.htm (consulted 1 October 2020)

Weseloh RM (2003) Predation/predatory insects in: Resh VH and Cardé RT (eds) encyclopedia of insects. Academic Press, Amsterdam, pp 945-947

Wheeler WM (1965) Ants: their structure, development and behaviour Columbia University press. York, New

Wikipedia (2019) Category: Ethnic groups in Africa by country. https:// en.wikipedia.org/wiki/Category:Ethnic_groups_in_Africa_by_ country. Accessed 1 Ocotber 2020

Williams VR (2020) Indigenous peoples: an encyclopedia of culture, history, and threats to survival. ABC-CLIO, Santa Barbara

Zimian D, Yonghua Z, Xiwu G (2005) Medicinal terrestrial arthropods in China. In: Paoletti MG (ed) ecological implications of minilivestock: potential of insects, rodents, frogs and snails, science publishers. Inc. Enfield, New Hampshire, pp 481-490

Publisher's note Springer Nature remains neutral with regard to jurisdictional claims in published maps and institutional affiliations. 